\title{
RESENHAS
}

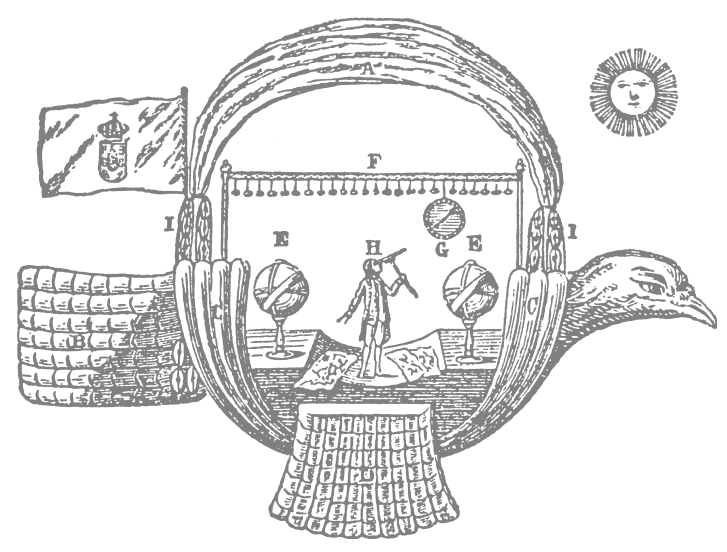





\section{ENTRE A INSPIRAÇÃO E O PRAZER DO TEXTO: ABRINDO CAMINHOS - HOMENAGEM A MARIA APARECIDA SANTILLI}

Elisa Guimarães

Universidade de São Paulo

$\mathrm{O}$

livro Abrindo Caminhos - homenagem a Maria Aparecida Santilli (São

Paulo, Editora Lato Sensu, 2002) abriga, em primeiro plano, um precioso manancial de informações, a começar pela apresentação do professor Benjamin Abdala Júnior.

Versos extraídos do Canto XXIX de Provérbios y cantares, de Antonio Machado, dinamizam o belo texto do professor que tomou para si a tarefa de apresentar a homenageada.

Assim, circunscreve-se a homenagem, na primeira parte do livro, ao apontar de caminhos que se vão abrindo à luz da atividade docente e de pesquisadora da professora Cida Santilli.

Passa, então, o leitor a acompanhar avanços abrindo caminhos para outros avanços, capazes de inovar a partir de uma tradição cultural sempre renovada pela pesquisadora em destaque.

Mente e olhos observadores, de mirada prolongada e profunda, pavimentam-lhe a estrada com o sólido cumprimento de nobres tarefas. Surpreende-se, então, infinito o espaço para a professora homenageada, que voa em qualquer tempo e pousa em qualquer campo - tão diversas são as rotas por ela abertas na militância docente, política e administrativa, presente e vivaz ao longo de mais de 40 anos.

Conforme assinala o professor Benjamin, a literatura realista de denúncia político-social vem se firmando como arena de sua atividade prioritária, de seu envolvimento profissional. 
Nesse embate, o feixe de observações críticas, superando extremos, sedimenta-se sobre um alicerce de rara independência de pensamento; corta as possíveis correias da sujeição, escapando acima de muitos limites, numa escritura crítica, contestatória e renovadora.

Assim, a habilidade e o poder envolvente de sua escrita, bem como de sua ação celebram-lhe não a vida represada como as águas contidas, mas a vida - sinal e oferta de estrada ampla e luminosa. Vida que se adivinha de trabalhos e vitórias, devidas, por certo, às suas qualidades de docente pesquisadora - para quem se aplicam com justeza os versos de Antonio Machado.

As primeiras páginas do livro-homenagem - expressão do talento do professor Benjamin Abdala Júnior - são, pois, testemunhas da abertura dos caminhos que, no rastro da passagem da homenageada, abrem um espaço sempre maior para as sementes que haverão de continuar germinando.

E o livro prossegue ao longo de mais de cinco centenas de páginas produzidas por 68 autores - amigos, colegas, alunos, ex-alunos, orientandos da professora Santilli, e representantes de diversas Universidades, ao lado de outras várias Instituições.

Assim, fazem-se presentes na composição da obra a Universidade de São Paulo - campo de atuação da homenageada - as Universidades Portuguesas de Lisboa, do Porto, de Coimbra, Nova de Lisboa; do Brasil, a Universidade Federal e a Pontifícia Universidade Católica do Rio de Janeiro, a Universidade Federal Fluminense, as Universidades Federais de Ouro Preto, de Pernambuco, de Goiás, de Sergipe, de Minas Gerais, de Uberlândia; a UNICAMP, as Universidades Católicas de Minas Gerais e do Rio Grande do sul, a Universidade de Mogi das Cruzes, a Universidade de Passo Fundo, a UNESP de Araraquara e de Assis, as Faculdades Metropolitanas Unidas; a Fundação Calouste Gulbenkian, a Escola de Jornalismo Casper Líbero, a Academia Paulista de letras, a União Brasileira de Escritores.

Escritores portugueses, brasileiros e africanos (moçambicanos, caboverdianos e angolanos) inspiram aos autores dos ensaios uma espécie de suma lingüístico-literária onde se cruzam e entrecruzam, num enclave sucessivo, os fios de uma rede de idéias e de formas. Teia habilmente tecida em várias pistas que se misturam e se recobrem na coexistência de instâncias múltiplas do processo criador. 
Porque amplos, os horizontes abarcam um sem número de investigações. Muitas linhas se compõem no desenho dos textos. E os artigos - independentes mas intercomunicantes -, vistos em perspectiva, vão se abeirando uns dos outros. Orquestram uma coletividade de significados, presidem um rico cruzamento de significantes, oferecendo, assim, o instrumento disponível para agenciar essa realidade conturbante que é a Língua.

Torna-se, pois, difícil apontar qual deles reflete com maior sensibilidade crítica os rumos do pensamento e as peculiaridades de expressão dos 68 autores em pauta, que mergulham e emergem para viagens no espaço e nas eras.

É como se segurássemos nas mãos um espelho poliédrico. Cada pequenina face revela ao leitor uma fisionomia diversa do fato histórico-linguístico-literário, matéria do livro.

A rica variedade de temas oferece o deleite da recapitulação de conhecimentos de Língua e Literatura Portuguesa, Brasileira e Africana, bem como de História, Lingüística Geral e de Texto, Estilística e Teoria da Literatura.

Assim, na diversidade de pressupostos culturais a que remetem o leitor, os ensaios encerram raro valor tanto de natureza crítico-literária, quanto documental e filosófica.

Ainda: a força dos textos reside em grande parte na sua conexão estrutural com o extratexto - conjunto de fatores históricos com os quais o texto se harmoniza, e que são condicionadores da intelecção da mensagem, da postura do autor, da mundividência demonstrada.

$\mathrm{Na}$ captação das inexauríveis dimensões de todo esse substrato, a fresta se amplia para um instantâneo revelador das virtualidades de criação dos autores. Inaugura-se, então, um espaço que se rege pelas infinitas possibilidades da " ars combinatória" da Língua e da Literatura.

É bem por esses caminhos que vêm trilhando os passos da professora homenageada, num perfeito equilibrio entre as fontes da inspiração e o sabor da linguagem. Difícil apontar um texto de sua autoria que não caiba nessa harmoniosa unidade.

É justo, pois, que os textos que lhe rendem homenagem estejam moldados a esse mesmo compasso.

Louve-se ainda a feliz iniciativa das professoras Benilde Justo Caniato e Elza Miné - responsáveis pela coordenação e edição do Abrindo caminhos. 